\title{
6
}

\section{What the neighbor to the west says Greek-Turkish relations}

\author{
It is only in a foreign Land that you can understand \\ that Greeks are your long lost brothers. ${ }^{1}$
}

There is nothing quite like a good quarrel with the United States or a crisis with Turkey, The Economist once commented, to persuade the Greeks to support their government; ${ }^{2}$ something the violent demonstrations during President Clinton's visit to Athens in November 1999 certainly confirmed. There is a seeming unanimity in Greece over their country's policies towards Washington and Ankara. However, unlike their uneasy, volatile relations with the United States, which tend to flare up at times of crisis, the Greeks are preoccupied with Turkey to the point of obsession. Their age-old conflict with their neighbor to the east absorbs them more than any other foreign policy issue. Considered a priority, Greek newspapers devote more column space to Turkey and related issues than to any of their European counterparts. Not so the Turkish press, which ranks the Greek-Turkish conflict only sixteenth in order of importance. ${ }^{3}$

It is a telling difference, representative of other spheres where the two countries differ in terms of their perception and response to events. Take, for example, the 1919-22 war. In Turkey, the war, which replaced the old Ottoman-Islamic loyalties with a new national consciousness, is seen as a war of liberation and patriotic resurgence. ${ }^{4}$ In Greece, it is regarded as the greatest tragedy of modern times, a disaster, which wiped out 2000 years of Greek presence in Asia Minor. Yet, it is incontestable that the war also inspired Greek unity. Previously, in the absence of common shared experiences, such as a national effort or war, most Greeks in Greece were not even aware that they were Greek citizens. The war and the need to absorb the over 1 million Greek refugees, who had been forced to flee Asia Minor, engendered a strong sense of Greek national unity and patriotism.

The 1919-22 war is only one of three traumatic events, which underlie and feed Greece's negative, often violent, feelings towards Turkey. The other two are the fall of Constantinople, in 1453, and the partition of Cyprus in 1974. 
Together, these three calamities delivered a severe and apparently final blow to the Megali Idea - the dream of a greater Greece embracing the "unredeemed" Greek and Hellenic lands in the Balkans, Asia Minor, the Aegean and Mediterranean seas - which had, over the years, provoked, an endless, often bloody irredentist conflict. It also accounts for Greece's tendency to challenge Turkey's integrity, embodied in the claim that as "As long as Constantinople is Istanbul, you don't belong to our kind." Constantinople, the capital of the Byzantine Empire, has a special, symbolic place in Greek consciousness. Controversy over the city can even bring a basketball game to an abrupt conclusion, as happened in December 1996 when the match between Aris Thessaliniki and Besiktas ended when the Turkish team spotted Aris supporters brandishing a sign stating "Constantinople is the capital of Greece" and refused to return to court after the first half. ${ }^{5}$

Not that Turkey, at least according to Greece, lacks regional ambition. Greece is convinced that Turkey's conquest of northern Cyprus is merely the first stage of a Turkish plan to impose a Pax Turkana in the Aegean and revive the Ottoman Empire. ${ }^{6}$ Greece worries that, unless Turkey is stopped in its tracks, a process of regional Finlandization will soon take place with Greece's defense and foreign policies, as well as its freedom of movement in the Aegean, Mediterranean and Ionian all being subject to Turkish consent and approval. Worse, Greece suspects that Turkish dreams go way beyond that of becoming a regional power and that Ankara seeks to wield power from the Adriatic to the China seas.

Turkey's global ambitions apart, Greece has long quailed at the thought that Turkey might seek to deflect its internal troubles by provoking a quarrel with Greece. ${ }^{7}$ The Greek horror of a communist onslaught faded in the 1960s, only to be replaced by growing fears of a potential Turkish threat, fed in part by Greece's acute consciousness of its relative military weakness. The 1974 defeat in Cyprus, Athanassios Platias confessed, laid bare the fact that Greece had no deterrent or offensive capabilities, other than those provided by the United States and NATO. And, he pointed out, in Cyprus the latter conspicuously failed to come to Greece's assistance. $^{8}$

Matters did not improve with the end of the cold war. Turkey, or so Greece enviously believes, found its place in the new postwar system. The Soviet Union's disintegration and the Persian Gulf's inherent instability inflated its regional importance. Worse, Turkey's goals and self-imposed roles in these and other areas, like the Balkans and Central Asia, have won the West's approval. By contrast, Athens bemoans, Greece, despite being a rock in a sea of Balkan instability, conspicuously failed to elicit Western support. President George Bush senior certainly thought Greece of negligible worth. Not so Turkey, whom he prized greatly, which was probably why on 20 July 1991, the seventeenth anniversary of Turkey's invasion of Cyprus - defined as "intervention" by Ankara - a sensitive date by all accounts, he tactlessly promised Turkey another F-16 assembly line. ' Small wonder that Greece, forlorn and forsaken, has been forced, or so it feels, to become "a lone wolf." 
The end of the cold war, Athens felt, only magnified the Turkish threat. Previously, in order not to shift attention and resources away from its battle with the Soviet Union, the West took great pains to prevent Turkey from attacking Greece. This was no longer the case, and Greece could not depend on the West to protect it against Turkish aggression. Furthermore, the vacuum in the Balkans, following the collapse of communism, whetted Turkey's appetite and encouraged it to try and regain its former position in the region. Remember, thundered George Papandreou, Greece's Foreign Minister, that

Turkey has always justified its occupation of Cyprus by claiming that it was protecting the island's Muslim-Turkish population, and who is to say that this will not serve as a precedent for future escapades in the Balkans? Undoubtedly, Turgut Ozal's talk of a new rising Ottoman Empire offer little comfort to Greek ears.

Neither, it is worth adding, does Ankara's tendency to refer to the Albanian and Bosnian Muslims as "brothers" and "sisters." "Greece often complains that it is the only NATO country whose territorial integrity is threatened by a fellow NATO member, with Turkey, or so Greece alleges, seeking to encircle it east and west. Not content with having a huge state, which already dwarfs Greece in the east, Turkey, Greece accuses, with Muslim connivance, schemes to do the same in the west. A host of issues divide Greece and Turkey, many of which center on questions of territorial and maritime sovereignty. Turkey, for example, has threatened to go to war if Greece dare to expand its Aegean islands' territorial waters from 6 to 12 miles. In 1996, the Turkish Prime Minister, Tansu Ciller, pronounced 3,000 islands and islets in the Aegean, Turkish territory, warning that Ankara would consider any attempt by Athens to take these islands by force a casus belli. In late January 1996, the two countries nearly came to blows over the Imia/Kardak islets, a few miles off the Anatolian shore alongside the Dodecanese islands. As this the first time Turkey had called into question Greek sovereignty in Greek territory, it is hardly surprising that the incident rang alarm bells in Athens. ${ }^{11}$ Equally worrying for Greece, is the fact that at an 80-100 percent degree of readiness, the Turkish forces stationed opposite the Greek Aegean islands are on higher alert than Turkey's other forces, which maintain only a 50 percent state of military readiness. Other points of Greek-Turkish contention include the fate of the Muslim Turkish minority in Greek Western Thrace, the rights to mine the minerals of the Aegean continental shelf, and control of the Aegean's air space.

But the biggest single Greek-Turkish dispute is Cyprus. As far as Greece is concerned the problem goes way beyond Turkey's occupation of the island's northern sector. Turkeys' greater military power means that it can dictate Cyprus's future. Neither is this Turkey's only strategic advantage. Unlike Greece, which lies at a distance of 600 miles from Cyprus, Turkey is a mere 60 miles away. Turkey is also blessed with a much larger population than Greece -65 million compared with 10 million - and so has virtually unlimited human resources at it disposal. Finally, Greece has to cope with the fact that its GNP is almost half 
that of Turkey's, and, as Athanassios Platias rightly pointed out, "the smaller the GNP, the fewer the resources devoted to the output of military goods, even if the proportion of productive capacity so allocated is very high.".12

The roll call of Greece's military disadvantages vis-à-vis Turkey is a long one. They include, other than those already mentioned, lack of strategic depth, lengthy and difficult to defend borders, the need to safeguard thousands of islands and islets scattered throughout Aegean, and population centers well within the range of Turkish artillery, all of which serves to tie up Greece defenses. Also Greece has inadequate road and rail networks, has only a short time to respond to a Turkish attack, especially in respect of the islands off the Turkish mainland, and there are no early warning systems registering Turkish incursions into Greek air space. ${ }^{13}$

The 1974 war in Cyprus encouraged Greece to rectify at least some of its military shortcomings. It established offensive units independent of NATO and expanded its navy and airforce, thus improving its ability to respond to Turkish threats and incursions. But, with 7 per cent of the national budget now devoted to defense needs, the burden on the Greek economy is heavy one. Indeed, with 4.8 percent of its GDP going to the army, Greece spends more on defense than any other NATO member. Turkey by comparison allots 4.4 percent of its GDP to defense. Five percent of Greece's labour force is employed in the military industry, again the highest percentage in NATO. And, Greece clearly means business, declaring that it will go to war should Turkey attempt to mine the Aegean's continental shelf's minerals to a depth of 200 meters or attack the Republic of Cyprus. Having stationing troops on the island which, acting as a tripwire, will ensure that a Turkish assault triggers an immediate and legitimate Greek response, demonstrates that Greece is all set to defend its rights. ${ }^{14}$

\section{A war of words}

The Greek-Turkish conflict has unleashed a flood of extraordinarily emotive rhetoric on both sides of the Aegean. Greece has a tendency to describe the lands it lost to Turkey in erotic terms, talking of the rape of Greece and the defilement of virgin Greek territory. Vamik Volkan and Norman Itzkowitz have noted that the Greeks, who see the Turks as a lust-filled nation, often liken the fall of Constantinople to rape. They speak of the youthful and virile sultan, who tore a hole in the city's walls and seized the Byzantine capital. Over the centuries, the figure of a fallen woman or grieving widow, often venerated in folk songs and poems, came to symbolize the city, now known as Istanbul.

Emotions run high on either side of the Greek-Turkish divide. The irascible Greek Foreign Minister, Theodoros Pangalos, had been heard to say that "we will have nothing to do with Turkey. A man cannot discuss things with murderers, rapists and thieves." ${ }^{15}$ The celebrated Greek author, Nikos Kazantzakis, swore that for the Greeks freedom means purging themselves of the corrupt 
Turkish traits acquired under Ottoman rule. ${ }^{16}$ The Greek Consul in Montreal took umbrage at a series of lectures held in a local university entitled: "Turkey: Two Millenniums of Art and History," protesting that the Turkish nation "had settled in the region much later" and that most of the discoveries cited were a part of the Greek cultural heritage. ${ }^{17}$

Pangalos's sacking in February 1999, following his part in the Ocalan fiasco more of which later - prompted the Turkish Daily News to reprint the minister's scurrilous remarks about Turkey, asserting that these

have ensured him a place in the history books. He has called the Turks "thieves, cut throats and sexual deviates". He has claimed that the fact that "every Turkish woman wishing to enter the civil service must undergo a virginity test", is proof that culturally Turkey is not European. Jacques Chirac's championship of Turkey's application to EU membership, led to him being compared to "the star of a beauty contest seeking to seduce the Turkish government". Finally, accusing Washington of dragging its feet over Cyprus, Pangalos, branded Bill Clinton "a gross liar" and called upon Greek Americans to stop donating money to the presidential election campaign.

It is high time, the paper observed "that Pangalos pay the price of his choleric behaviour and that the Greek government rid itself of a Foreign Minister incapable of acting like a diplomat." Diplomacy the Daily News, summed up "even when dealing with an arch rival cannot embrace those who refuse to accept its rules and, disseminating hatred, exhibit all the primitive emotions of a bankrupt statesman." ${ }^{18}$

Clearly, Turkey, no shrinking violet, could prove equally vicious when it came to criticizing Greece. In May 1996, the Turkish Defense Minister, Oltan Sougourlou, while insisting that "nobody in Turkey harbors any hatred or animosity towards Greece," let drop somewhat disingenuously that,

if anyone in Greece even dared to try to normalise relations with Turkey, he would be immediately accused of betraying his nation. What can one do with this kind of mentality. If we were to give them the whole of Turkey they would demand Central Asia. In World War II we rendered them every possible assistance, yet once the war was over, they exploited our naivete to secure various advantages in the Aegean. ${ }^{19}$

In December 1996, Tancu Ciller, Turkey's Foreign Minister at the time, boasted that Greece's fear of “our military might . . . is a well justified!" During a visit to Malaysia in August 1996, Prime Minister Necmettin Erbakan bemoaned Turkey's misfortune in "having Greece for a neighbor." As for Pangalos' insults, the Turkish Foreign Ministry, dismissed them as "impertinent . . . expressive of a psychopathological state of mind." ${ }^{20}$

In such a loaded cultural and political atmosphere, awash with negative, even abusive images, the chances that the two countries' relationship would improve appeared, at best, remote, at worst non-existent. Interviews with Greek and Turkish politicians, journalists, diplomats and soldiers confirmed this, rendering the prospect of a positive gesture, let alone compromise or concession, on the part of either, unlikely. Greek officials harped on the fact that Turkey 
possesses the largest army in Europe and that Istanbul alone has more citizens than Greece. Their Turkish counterparts pointed out that these were the very two reasons why Europe and Greece did not attack and lop off Western Turkey. "Turkey," the Greek ambassador to Turkey, Dimitirs Nezeretis, observed, upon leaving Ankara in February 1999, "is a big and tough country" and, he added, "I see no prospect of an improvement in Turco-Greek relations in the near future." ${ }^{21}$ It would take something dramatic, even cataclysmic to provoke a conspicuous change in Greek-Turkish relations.

As chance would have it, something sensational did happen and only hours after the Nezeritis interview. Unfortunately, its immediate effect was to exacerbate Greek-Turkish relations even further. On 16 February 1999, Ankara announced the capture of Abdullah Ocalan. It also made public Greece's part in the affair, the Greek embassy in Nairobi having given shelter to the PKK leader. Nor was this all, as Ocalan's arrest revealed the scale of the political military and logistic help Athens extended the PKK. As a result, Greek-Turkish relations hit an all time low. Some compared the Ocalan affair and its reverberations to those of the 1919-22 Turkish-Greek war and the 1974 crisis in Cyprus. The Turkish press called upon the government to react as vigorously as it had in the past to this new instance of Greek aggression and provocation. It compared Greece's cooperation with the PKK to Syria's overt collaboration with the Kurdish underground organization. And, it urged the government to warn Athens that unless it stopped supporting the PKK, it would become the target of a Turkish military operation, an ultimatum that had already proved itself in Syria's case.

In order to strengthen its suit, the Turkish media published a plethora of material proving Greece's close association with the PKK. It revealed that police in Edrine, having interrogated Kurdish detainees, identified Lavrion, in the southeast of Athens and an unnamed camp 45 miles north of Athens as PKK indoctrination and recruitment centers. In 1993, the Greek government gave the PKK permission to establish a branch of the Kurdish Red Crescent Society in Athens, to provide medical help to Kurds wounded in the war with the Turkish army. Greece also allowed the PKK to set up an office in Athens under the name “The PKK Representation in Athens." In 1994, the PKK's political wing, the National Liberation Front of Kurdishtan (ERNK), opened an office in Athens, which was in effect a PKK financial as well as recruitment and training center. The office also printed and distributed the Foni Tou Kurdistan - The Voice of Kurdishtan - and other subversive PKK publications. (In March 1997, the Kurdish publishing house, KOMAL, which was declared illegal in Turkey, resumed its activity in Athens). Finally, the PKK were able to collect a "revolutionary tax" from Kurdish asylum seekers in Greece, as in, for example, a camp at Patras..$^{22}$

Not that the Turkish government needed any encouragement. Furious, Ankara demanded, no less, Pangalos's extradition for his part in the Nairobi affair. President Demirel, denouncing Greece as country that supports terrorism, and warned that Turkey may well launch a military strike against the PKK bases in Greece. Visa exemptions for Greek tourists were abolished and NATO 
meetings between Turkish and Greek officers were held at junior levels only. Even Turkish businessmen refused to do business with Greece, and cancelled ongoing deals. Then, suddenly, within a few months everything changed. This time literally thanks to a cataclysmic event.

In August and September 1999 massive earthquakes hit both western Turkey and Athens. Greek and Turkish rescue missions instinctively rushed to each other's aid. People collected goods and donated money to help victims of the quake in both countries. Turkish and Greek newspapers paraded headlines such as "Brothers You Are Not Alone" and "Thank You Neighbor," and, what is more, in each other's language. ${ }^{23}$ The changed atmosphere was as dramatic as it was remarkable, indicative of the marked difference between the governments' and the people's attitude. While the former traditionally, almost automatically, tended to adopt a tough and uncompromising stand, the latter proved, at least in times of crisis, sympathetic and compassionate. But, the earthquakes also, as will be seen, had an effect on the politicians, encouraging them to reconsider other less dramatic developments and put them in perspective, to the benefit of the two countries' relationship. There is little doubt that the earthquakes and their aftermath have engendered a positive climate in both Greece and Turkey, which augurs well for the future.

\section{The Aegean and continental shelf}

In June 1995, Greece announced that, in accordance with the 1982 Convention on the Law of the Sea, it intended to expand the territorial waters around the Greek Aegean islands from 6 to 12 miles. Turkey, which observes the 12 mile limit in the Mediterranean and Black seas, but maintains a 6 mile limit around its Aegean islands, warned Greece against doing any such thing. If, Turkey explained, all Greece's more than 2,000 islands acquired a 12 mile limit the Aegean would become a Greek lake. With 64 percent of the Aegean Greek and only 24 percents left to the high seas, Turkish ships on their way to the Mediterranean would be forced to sail through Greek waters. ${ }^{24}$ Consequently, Turkey declared, if Greece went ahead with its plan, it would have no choice but to declare war.

According to Athens this particular quarrel goes back to the 1970s and Turkey's unflagging efforts to gain control of the Aegean. It points to Turkey's refusal, since 1974, to respect the Greek Aegean islands' air space and the Athenian Flight Information Region (FIR). Turkey counters this by pointing out that Greece has failed abysmally to fulfil its FIR responsibilities, noting sarcastically that "though it manages 7 percent of all air traffic in Europe, Greece is responsible for 30 per cent of all delays." ${ }^{25}$ In August 1974, Ankara issued a Notice to Airman (NOTAM), number 714, which moved the information line for aircraft approaching Turkey several miles west of the previous Turkish Aegean FIR. As a result, most of Greece's Aegean islands suddenly found themselves east of the 
new FIR line and under Turkish jurisdiction. Athens reacted strongly, exclaiming that the Aegean FIR was fixed by the International Civilian Aviation Organization in 1952 and that Turkey had no right to shift it. Athens also complained that Turkey had failed to observe the Greek islands' air space set at 10 miles. Recognizing only a 6 mile limit, the Turkish air force regularly violated the islands' air space. Unfortunately, interception attempts by the Greek air force have multiplied the danger of dogfights.

Turkish demands for a share in the Aegean continental shelf's mineral and oil reserves also exasperated Greece. The Turkish claim, Athens argued, contravened the Lausanne agreement of 1923, which awarded Greece the entire Aegean, other than the Turkish coast. Moreover, Greece is in desperate need of the shelf's mineral wealth, which contains its only oil field - in Prinos, southwest of the island of Thassos - though it, too, is running dry. In the 1980s Greece produced 1 million tons of oil a year, but by the 1990s this dropped to a paltry 600,000 tons.

In order to prove its charges of Turkish territorial and financial cupidity, Greece brandished an official Turkish textbook, published in 1997, which declares that the Aegean islands are an extension of the Anatolian continental shelf, thus insinuating that the islands have no continental shelf. Athens is equally sensitive to Turkey's insistence that the Aegean and its islands have always belonged to Anatolia, implying that Greek control of the islands is, at best, temporary. Then there is Tansu Ciller's claim to 3,000 islets and rocks, some of which are hundreds of miles from the Turkish coast, and most of which have been under Greek sovereignty since 1913. Quoting Turkey's own descriptions of itself as a regional power with interests throughout the Ionian Sea, Athens protested that it is subject to "Turkish territorial claims ... ranging from the Evros river in northern Greece to the Aegean islands as far as Crete." Moreover, it accused, ever since 1995 Turkey has deliberately provoked crises in the Aegean in order to challenge Greece and impose its will on the area. Greece worries that it will find soon itself, in a regional version of Finlandization, "having to co-ordinate our defence and foreign policies with Ankara in an area ranging from the Aegean to the Ionian."26

Worse, Greece fears that Turkey will one day try to seize the islands by force. The fact that Turkey's Fourth Army - the Aegean Army - is stationed along Greece's borders serves only to augment Greek anxieties. Numbering 35,000 troops and equipped with landing craft, the Fourth Army is the second largest force in NATO, though independent of NATO. No less alarming is the deployment of Turkey's three other 650,000-strong armies. Turkey's First Army, stationed in Thrace, is a formidable military force, which lies only a stone's throw away from potential Greek targets. Turkey's Second Army, deployed in southeast Anatolia opposite Syria, Iraq and Iran, spends most of its time fighting the PKK and quelling insurgencies in the southeast. The Third Army is in charge of Turkey's eastern and Georgian frontiers. ${ }^{27}$

Greece, has to face this powerful military force with an army of less than 115,000 men. Its elite force - the Fourth Army Corps - is charged with defending 
the Greek-Turkish borders in Thrace and the Aegean. The First and Second Army Corps - by far weaker - defend Greece's northern frontier. The Second Army Corps is, however, in the process of becoming a rapid deployment force. The air force and navy maintain Greek air superiority and control of the Aegean. ${ }^{28}$

\section{The arms race}

While most countries are intent on slashing their military budgets, Greece and Turkey are spending more money on arms than ever. Greece, currently imports 95 per cent of its military equipment, with only 5 per cent produced domestically, a dramatic fall from the 20 per cent figure of 1990. According to the Greek newsletter COSMOS, Greece has a long way to go before it achieves the target of a 50:50 imports and domestic production ratio set in the early 1990s. ${ }^{29}$ The reason is simple, small countries like Greece find it extremely difficult to create a modern, efficient arms industry. Their diminutive domestic market renders the costs of production extraordinarily high. Nor is it, as Greece has discovered, always easy to cut expenditure by importing technology or using substitutes. As a result, in the few cases where Greek components were used, their added value was frequently well below the 40 per cent mark. ${ }^{30}$

Between the end of the 1990s and 2007, Athens means to spend some 16 billion dollars on arms. It will acquire 35 percent of these weapons from the United States, much less than the 80 percent it purchased in 1974. Greece's extensive shopping list includes, AWACS, early warning aircraft, fighter jets, helicopters, transport planes, pilot training systems, upgraded F-4 phantoms and tanks, anti-aircraft systems, submarines, capital warships, torpedoes, corvettes, and missile boats. Greece also plans to improve its military capabilities in such critical areas as command control, communications, computing, intelligence and information warfare, the conduct of extended military operations, air and sea control, armour-based fire-power support, air defenses, and troop endurance and survival ability, all of which cost money too. Finally, according to Andre Gerolymatos, Greece is in the process of replacing the division, as the organizational unit of command, with brigades and battalions, which will enhance the army, navy and air force's ability to function as a single integrated force. It will also improve mobility, essential if Greece is to cope with the multiple Turkish threat. ${ }^{31}$

Turkey military spending program calls for 150 billion dollars to be expended in the first quarter of the twenty-first century alone. Ankara justifies this mindboggling sum by pointing to, among other things, Greece's huge defense bill, noting that proportionally it is the highest in NATO. Turkey's land forces will receive 60 billion dollars, with which they will buy 48,564 wheeled vehicles, 750 helicopters, 3,627 main battle tanks, 1,951 guns and howitzers, 180 rocket and missile systems, 150 anti-tank rockets, and 12 remote control air vehicles. The navy will get 25 billion with which to purchase 38 helicopters, 35 landing vehicles, 
25 auxiliary class ships and vehicles, 16 patrol ships, 15 guided assault boats, 14 frigates, 12 corvettes, 9 submarines, 4 anti-mine ships, 4 mine sweepers, and 1 communications ship. The air force, allotted the sum of 65 billion dollars, will acquire 640 fighter jets, 442 air defense weapons systems, 160 training aircraft, 79 operations planes, 68 transportation planes, and 25 helicopters. ${ }^{32}$

The vast amounts Greece and Turkey plan to spend on arms mean that they are in effect mortgaging their future. There is little doubt that the citizens of both countries would much prefer it if these gargantuan sums were used to finance various essential civilian projects. Certainly in Turkey there have been calls - which have grown louder since Ocalan's capture and the effective end of the war against the PKK - to devote more money to the country's twenty-six eastern and southeastern war-torn provinces. Local businessmen have already taken steps to relieve the region's economic plight. Firms, owed money by Iraq, money they have little chance of seeing, banded together to set up a company that will import oil - to the tune of 7 million tons - from Iraq in lieu of the Iraqi debt. This, Prime Minister Bulent Ecevit, waxed enthusiastically, will help kick start the local economy because on average, as he calculated, over the next two and half years, 500 fuel tankers will arrive daily in Turkey and 15,000 vehicles will be put to work. "Given that each vehicle employs 20 people this means 300,000 jobs," he declared. Moreover, Ecevit hoped that Turkey would gain transportation revenues, companies would increase their profits and the state's tax revenue would grow. Iraq would also benefit and would purchase with its oil revenues local merchandise, thus stimulating business in Turkey's southeast. ${ }^{33}$ The government in Ankara, sensitive to public opinion, also did its bit to help. Ecevit promised 100 million dollars in aid. Factories in the region were offered long-term low-interest loans, tax exemptions, and generous reductions in the price of electricity. The government announced that it would award displaced Kurdish villagers grants to encourage them to return home, and, Ecevit proudly proclaimed, 1,000 families had already taken advantage of this offer. Finally, the government promised to triple its investment in the east and southeast.

Yet, impressive as this is, it is far from enough. The number of displaced persons in the region is thought to be 4 million. Unemployment has reached the 3 million mark. Farmers, whose numbers have been reduced by 75 percent, have been particularly hard hit. Fifty-three schools, accommodating 20,000 children, were planned for 1999, with another 72,000 children to be provided for the following year. On the industrial front, there are plans for eleven official industrial zones expected to create 32,000 new jobs. Also in the pipeline are eleven power-producing and transmission facilities plus four portable power plants, each capable of generating 75 megawatts of electricity. The sums needed for these and other similar projects are estimated at 1.8 billion dollars per annum..$^{34}$ It must be said that this massive figure is dwarfed by the vast amount, 80 billion dollars according to official Turkish sources, Turkey has spent battling with the PKK. Some, however, claim this to be a laughably conservative estimate and that the real outlay was $7-15$ billion dollars a year, which over the 
fifteen years of the PKK insurrection (1984-99), adds up to the incredible sum of 225 billion dollars. ${ }^{35}$

Offsetting these urgent domestic needs is the reluctance of various interested parties in Turkey, particularly within the military industrial field, to cut their budgets and surrender the rich pickings afforded by continued military spending. Money is also needed to pay for the damage wrought by the 1999 earthquake. The earthquake had a disastrous effect on Turkey's economy, 35 percent of the country incurring some form of damage. Turkey's industrial and commercial sectors were particularly hard hit, suffering losses of 42.5 percent and 34.6 percent, respectively. Given the urgent need to revive Turkey's economy, it is unlikely that the southeast will receive the money it needs. Yet, even the desperate need to allocate money to reconstruct Turkey's quake-stricken areas has failed to persuade the military to reduce its budget: most of the weapon procurement plans have survived the earthquake largely intact. The 2000 military budget was set 7.6 billion dollars or 8.8 percent of the annual budget, a negligible change from 1999. Aware that since the winter of 2001 Turkey has been facing a severe economic crisis, the military has agreed to postpone, at least temporarily, its 19.5 billion dollar modernization program. It is worth noting that the army believes that the 150 billion dollars earmarked for buying weapons, falls far short of Turkey's real needs. Surely, this figure will, despite promises to spread the arms purchases over several years, hamper efforts to curb Turkish inflation. And, this, together with all the other urgent economic exigencies it faces, should give the government pause for thought; it might be that the Turkish-Greek thaw might after all result in the transfer of monies from military to civil needs. ${ }^{36}$

In Greece, too, the government has, following the thaw in Greek-Turkish relations, faced pressure to cut military expenditure and divert the money thus saved into vital domestic programs. At the time, the Greek government was well aware that Greece was the only EU country that had failed, owing to its poor economic performance, to join the European Monetary Union (EMU), and was anxious to improve its economic management and meet EMU standards. Greece was to become an associated member of the EMU in March 2000; full membership was to follow in 2001. Eventually, Athens did join the EMU. But before accession, few conditions had first to be fulfilled, among them that the drachma's exchange rate was to remain stable for at least two years. Indeed, Greece did achieve an impressive number of fiscal and economic achievements - inflation has fallen from 15 percent in 1993 to under 4 percent in 1999; the country's fiscal deficit in the late 1990 s, was slightly above 8.8 percent, a marked improvement on 1993's 13.7 percent (but still far from the EU 3.7 percent); the 1996 growth rate showed a 2.6 percent upward trend, well above that of the EU; in 1998, there was a 10 percent increase in public and private investment as opposed to 4.5 percent for the EU. Still, Greece had some way to go before it conformed to EMU norms. It had to reduce inflation to around 2.5 percent; improve its debt:GNP ratio, which though it had fallen from 105.5 percent in 
1996 to 100.7 percent at the end of 1998 , was still among the highest in the EU; reduce the textile and agriculture sectors' share in the country's GNP, which at 21 percent was much larger than that of other EMU members (agriculture accounts for 2.4 per cent of the EU's entire GNP); and curtail cotton production in line with EU policy (fast replacing other crops, cotton has become a growth industry of vital importance to the Greek economy). Greece had also to cut the prime interest rate from 10.75 per cent to 3 per cent as in other EMU countries. ${ }^{37}$ As noted, in 2001 the country did become a party to the EMU, and complied with its standards; presumably, the Greek-Turkish thaw enabled the transfer of monies from military to civil ends.

In view of the above it is tempting to think that these urgent economic demands may ultimately persuade Greece and Turkey to divert money from the military to much needed domestic projects. This, in turn, may help alleviate Greek-Turkish tensions. In any case, awareness of the need to cut their military budgets may well have prompted both sides to start negotiating with one another.

\section{The United States}

Athens' criticisms of the United States boil down to two closely related complaints: the Americans' total disregard of the historic basis of many of Athens' claims and their unwavering pro-Turkish stance. Athens is convinced that the Republican Party traditionally and instinctively favors Turkey over Greece. Certainly the Bush senior administration has proved itself a particular Greek bugbear, while Greece has no doubt that Bush junior will follow in the footsteps of his father.

Greece claims that as a young nation, the United States has absolutely no sense of history. As far as the Americans are concerned the past began in 1945, which is one reason, why they find it so difficult to understand Greece's quarrel with FYROM over the right to the name Macedonia - Greece insists upon calling the Former Yugoslav Republic of Macedonia (FYROM), underlining its sole historic claim to the name Macedonia. ${ }^{38}$ Moreover, having burst onto the international stage in 1945 and at the outset of the cold war, the United States found Turkey to be a much more valuable ally than Greece, particularly in its battle against the Soviet Union and communism. This bias continued well into the late 1980s and 1990s. In order to secure Turkish cooperation during the Gulf war, Washington put the Cyprus dispute on hold. Ignoring Greece's insistence on the strong parallels between Iraq's invasion of Kuwait and Turkey's acting likewise in Cyprus, President Bush announced that Cyprus would not be included in the American search for peace in the Middle East. The dispute in Cyprus would be turned over to the UN instead, which effectively meant deferring the solution to the crisis perhaps indefinitely. The United States justified its decision to abandon Cyprus, which was particularly jarring in light of its relentless efforts to resolve the Arab-Israel and Balkan conflicts, by pointing out that while the 
Arabs and Israelis had exhibited a willingness to negotiate, such was not the case with Greece and Turkey.

The question of American military aid to Greece and Turkey has also led to Greek protests of unequal treatment and pro-Turk bias. In 1980, Greece finally persuaded Congress to pass a series of laws, guaranteeing Greece 7 dollars worth of military equipment for every 10 dollars of equipment Turkey obtained. But, Athens suspected that the White House, unhappy with this development, was simply waiting for the opportunity to revoke this ratio. In 1991 its forebodings were realized when, following the Gulf War, Washington effectively quashed the 7:10 ratio. It awarded Turkey a sizeable grant, while Greece had to be satisfied with a considerably smaller loan. It also sold Turkey far more sophisticated weapons than anything Greece possessed. True, the 7:10 ratio was reinstated in July 1991, but it has since, owing to Greece's and Turkey's massive arms procurement programs, largely fallen by the wayside. ${ }^{39}$

To Greece's dismay the Democratic Clinton Administration proved no better than its Republican predecessor, keeping up a steady flow of arms to Turkey to the tune of 800 million dollars per year, or 4.6 billion dollars in its first six years in office. In 1997, the path was cleared for Boeing and Bell Textron to bid for a 4 billion dollar contract to sell Ankara 145 advanced attack helicopters. ${ }^{40}$ By the end of the 1990s, Turkey had become one of the United States' major arms buyers, second only to such favored clients as Saudi Arabia, Taiwan, Israel and Egypt.

Given the above, Athens concluded that the United States has always, and possibly will always, side with Turkey against Greece. Ocalan's capture clinched matters. "Nobody," railed Pangalos, Athens' soon to be dismissed Foreign Minister, "Believes that the Kenyans handed Ocalan over to the Turks. There were" he said, hinting that the United States had taken an active part in Ocalan's capture, "some very big, blond men involved in the affair." Other less vicious minds agree that the United States, which had long regarded Greece as a trial and a nuisance, sent agents to help Turkey seize Ocalan, but only because it wanted to prevent Turkish retaliatory action against Greece. This made little difference to Pangalos who, unrepentant, continued to upbraid the United States: "some people in the United States want its friends to constantly say 'yes'. Well though a friend of the American people, I refuse to be anyone's slave." ${ }^{11}$

The assistance rendered Turkey by the Jewish and Israeli lobbies in the United States has also made life hard for Greece, which in any case finds it difficult to promote its cause in Washington. Not that life in Washington is easy for Turkey either. Ironically, Nuzret Kandemir, Turkey's Ambassador to the United States, has claimed that the toughest part of his nine-year stint in Washington was his battle against the Greek, Greek-Cypriot, Kurdish and Armenian lobbies. Working in Washington, Kandemir sighed, "is like taking an exam." ${ }_{42}$ 


\section{Cyprus}

Cyprus is the principal source of Greek-Turkish enmity. The two countries' hold utterly conflicting views of the island's past, present and future, and particularly of the 1974 crisis. Greece believes that Turkish nationalism - a relatively new phenomenon dating from 1923 - feeds upon expansionist démarches, like that of Cyprus in 1974. It is convinced that Turkey regards Cyprus as a bridgehead for further territorial expansion. Consequently, Greece reasons, it has no choice but to fortify Cyprus's remaining Greek portions. Turkey, for its part, insists that its intervention in 1974 was a rescue mission, born of its commitment to the welfare of fellow Muslims and nationals, whom the Orthodox world seeks to eradicate.

Greece dismisses Turkey's account of its actions, pointing out that, having conquered the island's northern portion, it then set about altering its demographic make-up by settling Anatolian Turks in the area under its control, and, Greece protests, on land belonging to the some 250,000 Cypriot Greeks, who had been forced to abandon their homes in 1974. (There are currently less than 500 Greek Cypriots left in Turkish Cyprus.) This settlement policy, Greece claims, is particularly insidious, as the Cypriot Turks have long maintained a separate identity and culture from their mainland cousins. They may share a language and religion, but, even here, there are subtle differences between the two. According to Greek sources at 114,000 the mainland settlers greatly outnumber the Cypriot Turks, who total a mere $88,000 .{ }^{43}$ This glaring imbalance owes much to the fact that since 1974 a large number of the island's Turkish inhabitants have left for Britain and Malta, while over 80,000 mainland Turks have immigrated to northern Cyprus. It is a case, Greece complains, of "a Turk leaves and a Turk comes." The result is that while in 1960, Cyprus's Turkish population numbered 160,000, by 1998, that number rose, according to the Turkish Republic of Northern Cyprus (TRNC), to 198,000. The Turkish Cypriot daily newspaper, Avrupa, further disclosed that 70 percent of the TRNC's bank employees, 75 percent of its restaurant owners and 90 percent of its jewelryshop owners are Turkish settlers. ${ }^{44}$ These figures, Athens remarks snidely, entitle the TRNC "to inclusion in the Guinness Book of Records," as despite the wholesale emigration of the Cypriot Turks the island's Turkish population just keeps on growing and growing. 45

Greece also accuses Turkey - an accusation Turkey vehemently denies - of sending the "Grey Wolf," a hard-line nationalist paramilitary youth organization (Bozkurt) to Cyprus. These thugs, Greece charges, took part in the summer of 1996 in a number of violent incidents along the border separating Greek from Turkish Cyprus. According to George Papandreou, the Grey Wolves were also implicated in the forest fires that raged throughout December 1996 on several Greek islands including Cyprus. ${ }^{46}$

Turkey has a 35,000-strong expeditionary force on Cyprus. The Eleventh Army Corps, part of Turkey's Second Army based in Malatya, Turkey, is a 
formidable military force. Commanded by a Lieutenant General, it consists of two infantry divisions, the Twenty-eighth and Thirty-ninth, plus an independent armored brigade, the Fourteenth, which has at its disposal over 100 firstclass tanks, approximately 100 personnel carriers cum fighting vehicles, and self-propelled artillery. Then there is the indigenous Turkish Cypriot force numbering some 5,000 men, who serve as light infantry. ${ }^{47}$ According to Greece, the Turkish expeditionary force has its own agenda, often quite different and as a rule more hard line than Ankara's. Enjoying a great deal of leeway, the Eleventh Army Corps, Greece inveighs, behave in much the same way as the Japanese did in Manchuko during the 1930s. ${ }^{48}$

The island's Greek sector is also awash with soldiers - the Republic of Cyprus vies with Israel and Lebanon for the title of the world's most heavily armed region - charged with defending it against further Turkish incursions. However, given that the Greek portion of Cyprus is only a few minutes' flight away from Turkey, but 600 miles away from Greece, this is no simple task. The logistical problems are immense and in an attempt to overcome them, Greece decided, among other things, to station Soviet-made anti-aircraft missiles worth some 500 million dollars - on the island and thus safeguard the aerial corridor between Greece and Cyprus. But, Ankara, drawing attention to the fact that with a range of 150 miles these missiles could easily penetrate Turkish air space, insisted that the missiles were offensive rather than defensive weapons and threatened to go to war should Greece proceed as planned. To prove their point, Turkish sources quoted Theodore Pangalos's boast that "the Greek Cypriots ordered only 38 missiles, which, if used, will eventually destroy only 38 Turkish aircraft." ${ }^{49}$

Turkey's fierce reaction, and the prospect of a new Greek-Turkish imbroglio, persuaded Athens and the Republic of Cyprus to reconsider the matter. Eventually, after much acrimonious discussion, they decided to station the missiles in Crete, 500 kilometers from the TRNC - which is thus well within the missiles' radar range - but 150 kilometers from the Turkish nearest coast. The missiles, owned by the Republic and manned by Greek Cypriots trained in Russia, would be under mainland Greek command. Turkey, however, was far from satisfied. Condemning the decision as "inadmissible," it warned Greece that it was making "a huge mistake."

According to Athens, it decided to redeploy the missiles, mainly because the "conflict in Cyprus and particularly its militarization, consistent with Ankara's thinking, works to Turkey's advantage." Hence, Greece must focus upon politicizing the problem. It is why, for example, the government explained, the Republic's accession to the EU is a priority. Unfortunately, this meant, the government then pointed out, that it had to abandon the plan to station the S-300 missiles on Cyprus. Neither the EU not NATO would welcome into their ranks a country embroiled in military conflict, that has weapons systems which may provoke a Turkish attack, and that employs Russian technicians to maintain them. One need only listen to NATO's - whose code name for the missiles is 
Grumble - mutterings that had the missiles been stationed in Cyprus their radar systems, manned by Russians, would have been able to monitor NATO aircraft flying over the Balkans.

These explanations failed to convince, let alone appease the Greek government's right-wing and opposition critics. Branding it as "the greatest humiliation Hellenism has suffered," they saw the decision to redeploy the missiles as proof of Greece's military weakness - some said helplessness - vis-à-vis Turkey. Greek right-wingers were similarly vociferous when Turkey grabbed Ocalan outside the Greek embassy in Nairobi, denouncing the government as "a government of Quislings" and hinting at high-level collaboration. The whole point of the missiles, opposition circles exclaimed, was to convince Turkey of the effectiveness of the Greek-Cypriot Unified Defence Doctrines (UDD). By removing them, and surrendering Greece's long-range capability, the government had achieved precisely the opposite, proving to the Turks that the UDD is utterly worthless. Moreover, the S-300 deployment, intended to add "a sharp edge to the UDD's strategic bargaining power, backfired badly," because, yet again, "Athens and Nicosia were oblivious to Turkey's well known and violent objection to any form of military bluffing." ${ }^{\prime 50}$ Yet, whatever the government's critics might think, it is clear that the S-300 scheme failed to deter Turkey, who went ahead anyway and threatened Cyprus. Neither was Ankara highly impressed by the growing military ties between Greece and the Republic of Cyprus. But these very contacts, like Athens's growing military investments in the island, specifically sought to deter Turkey. ${ }^{51}$

Paradoxically, the S-300 affair signalled the onset of a more positive era in Greek-Turkish relations. It drove home to Greece the fact of Turkey's superior military strength. At the same time, the Greek decision to redeploy the missiles, thus rendering the UDD less of a threat, removed one of the many barriers to a rapprochement between the two countries. Furthermore, by forcing the two countries to talk rather than confront each other, it helped ease Greek-Turkish tensions in general. Finally, in Ankara, officials, well aware that Athens had yielded to Turkish might, felt sufficiently confident to consider the possibilities of a détente. When within a few months Greece once again bent to Turkish pressure, this time over Ocalan, both sides were ready to embark upon the earthquake-inspired diplomacy of August-September 1999.

\section{Cyprus and the European Union}

Highlighting Ankara's threats to annex the TRNC if the Republic of Cyprus is admitted to the EU, Greece accuses Turkey of blackmail. Greece claims that Turkey will consider letting the Republic enter the EU only if it is allowed to join the organization first. Turkey vehemently denies this and insists that its opposition is based purely upon the 1960 Cypriot constitution, which states clearly that Cyprus cannot subscribe to any organization, including the EU, that does not 
include Greece and Turkey; an argument that raises the suspicion that Greece is right and Turkey is angling for EU membership. Greece, which ardently supports the Republic's application for EU membership, retorts that the current state of affairs in the island has rendered at least this part of the constitution irrelevant. The constitution, it explains was designed to prevent Enosis - the unification of Greece and Cyprus - not block the island's membership of international bodies. Besides, asks Greece, how come a state, that is to say Turkey, "that has broken a treaty can invoke that treaty for the purposes that suit her. Partition [of Cyprus since 1974] . . is one breach. Recognition of the state that is consequent of partition [the TRNC] is a second breach." ${ }^{52}$ As if blackmail were not enough, Greece also credits Turkey with deliberately and artificially exacerbating the situation in Cyprus in the hope that the EU will balk at admitting to its ranks a country engaged in an fierce ethnic dispute.

The Austrian precedent is not a more convincing case as far as Ankara is concerned. The Austrian State Treaty of 1955 prohibited union between Austria and Germany, in the same way as the 1960 treaties in regards to Cyprus specifically negated Enosis between Greece and Cyprus. Yet, in 1995 Austria was allowed entry into the EU, thus establishing an indirect union between Vienna and Berlin. Why should not Cyprus be allowed to do the same, asks the Hellenic world? The Turkish reply is clear: in the 1960 Cypriot Treaty of Guarantee, each community has a veto over membership of international organizations unless Greece and Turkey are parties to it, which is not the case with the EU where only Greece is a member. In the Austrian case all the parties to the Austrian State Treaty agreed to Austria joining the EU, even Russia, which in 1955 insisted on avoiding repetition of the Anschluss. "If states all agree to interpret their treaty in a particular way, or to waive a breach of the treaty that is fine. But this is not the case here because one of the parties to the [Cypriot] treaty, Turkey, does not agree." ${ }^{\text {53 }}$

Whatever the truth behind the Greek accusations, it is worth noting that one of the reasons Turkey objects to "Greek Cyprus" admission - the Turkish riposte to Athens and Nicosia's "the so-called TRNC" or, more generally, "the pseudo state;" Greece also tends to girdle its references to TRNC officials with inverted commas, for example, "the Prime Minister of the pseudo state" - is that the EU would then have two anti-Turkish Greek states. Worse, the Republic's admission but not the TRNC's will, Turkey fears, fix once and for all, at least in Europe's eyes, the border between the Hellenic and Turkic worlds. Warning that the accession of a divided Cyprus will cause an irreparable breach between Turkey and Europe, Ankara insists that the EU will not discuss Cyprus's admission until certain conditions are met. It further demands that the EU treat the Republic and TRNC equally, as two independent states. ${ }^{54}$

Not that Ankara is overjoyed at the prospect of the TRNC joining the EU. Indeed, the possibility that the TRNC will become a member of the EU as part of a process at the end of which the entire island will join the $\mathrm{EU}$, has provoked a great deal of acrimony, this time between Turkey and the TRNC. Ankara insists that the Cypriot Turks join the EU only after Turkey, to which the TRNC 
has retorted that Ankara cannot keep on treating it like a baby, that the two countries are equals, and that it should be treated as such. This truculent response is somewhat surprising, given that, except for Turkey, the TRNC is boycotted by the rest of the world, and its economy is totally dependent on Turkey's. The TRNC's annual inflation is 58 percent and it has 4,000 dollars GDP per person; the Greek Cypriot Republic boasts a 4.8 percent inflation and 14,000 dollars GDP per person. ${ }^{55}$ In any case the prospect of the TRNC joining the EU as part of a package deal is at present non-existent, which makes the passions the issue arouses all the more extraordinary.

\section{Cyprus's future}

Greece's solution to the Cyprus imbroglio - a bizonal, bicommunal state with both the Greek majority and Turkish minority enjoying equal political rights is far removed from Turkey's vision of the island's future. Greece, for one, is convinced that Turkey, seeking to consolidate it control over the TRNC, has absolutely no interest in reuniting Cyprus. Nor is it in any hurry to resolve the conflict, given that with every passing day its links with the TRNC grow stronger and more extensive, while the prospect of unification retreats into the distance. Certainly, Ankara, despite some 1,000 ethnically based incidents per year, hails Cyprus as a shining example of a conflict in which partition produced stability, though not admittedly tranquillity. But, counters Greece, it is a false stability, totally dependent on the UN troops' success in separating the two communities.

Turkey's policy on Cyprus hinges, Greece believes, on two external, extraneous considerations. The first, pan-Turkism, predisposes Ankara to shun any compromise for fear of prejudicing its ties with Muslim or ethnic Turk elements in the Balkans, Caucasus and Central Asia. The second, and more important issue, already mentioned, is the EU, and Turkey's insistence on holding the island hostage to its ambition to join the EU. Turkey will only, Greece contends, abandon its uncompromising stand on the dispute if admitted to the EU.

Just as Greece accuses Turkey of neo-Ottomanism and dreams of a new Ottoman Empire, Ankara reproaches Greece with wanting to revive the Byzantine Empire. Athens's prospective empire, Turkey avers, will embrace the entire Aegean, and its capital will be Istanbul - the much coveted and sorely missed Constantinople. In line with its ambitions Greece, or so Turkey claims, is intent upon dispossessing the Cypriot (and Thracian) Turks. As evidence, it points to Greece's tendency to refer to the island's Turks as "Muslimized Greeks," which certainly smacks of colonial inclinations ${ }^{56}$ Turkey and the TRNC fear that once Cyprus is unified the island's Greek majority, adopting the policies of their mainland compatriots, will seek to suppress the identity of the Cypriot Turk minority.

Turkey finds the Greek goal of Enosis equally unacceptable, and sees no reason to assume that Greece has abandoned that, to its mind, iniquitous idea, which has led to the mass murder of hundreds of Cypriot Turks. In fact, Ankara 
claims, once Cyprus is unified and the proponents of Enosis prevail, there is every chance of history repeating itself. Nor has Turkey much faith in EU ability to safeguard the island's Turks, given its poor record in preventing the slaughter of Muslims. Who is to say, Ankara contends, that what happened in Bosnia, where Orthodox Serbs massacred innocent Muslims under the impassive eyes of EU troops, will not take place in a unified Cyprus, whether it joins the EU or not. Only this time it will be a case of Orthodox Greeks killing Muslim Turks.

The Cypriot Turks insist that in 1974, they, with Turkey's assistance, acted wholly in self-defense. They point out that there is not a single Turkish family on the island who has not lost at least one of its members to Greek violence. But, declared Rauf Denktas, the TRNC's president, when interviewed by an Israeli journalist, "we will survive just as you survived the Holocaust," leaving the journalist with the distinct impression "that Hitler and Greece retain an overwhelming presence in the TRNC." ${ }^{57}$ Not that the Cypriot Turks are the only ones to have suffered. The Republic of Cyprus's museums are full of horrifying pictures of savagely beheaded Greek-Cypriot children. It would thus appear that the principal barriers to a settlement in Cyprus are fear and mistrust. At present, the Cypriot Turks swear that only mainland Turkey can guarantee their safety. The Greek Cypriots deny this, and demand the withdrawal of the 35,000-strong Turkish force as well as the return of some territory currently in the hands of the TRNC. ${ }^{58}$ The Cypriot Turks reject this demand, emphasizing that unlike Turkey, Greece has no legitimate claim to Cyprus. After all, they observe, the island was under Ottoman not Greek sovereignty for 300 years, adding that Turkey would find it insupportable to lose a second territory in the island, in addition to the southern part already lost to the Greeks. ${ }^{59}$

Cyprus is a typical post-cold war conflict, a mixture of ethnic and religious questions which, together with historical undercurrents and external intervention, combine to create a complex and unwieldy problem. The fact that partition apparently works, and calm prevails, renders a satisfactory solution to the affair all the more difficult. However, if Turkey does eventually soften and agree to a compromise settlement, it will probably come in the form of a confederal Cyprus, perhaps a loose federation whose Turkish part will receive maximum autonomy, practically verging on sovereignty, and whose security will be guaranteed by the physical presence of Turkish troops. Not a minority, not a community while the other side enjoys the status of a state, not a weakened party to a federation, but a separate, equal and legitimate entity within a confederation - this is the mantra of the Turkish side to the conflict. ${ }^{60}$ As Ismail Cem, Turkey's Foreign Minister, explained: "We want Cyprus to continue as a political entity, even if it is called the Confederation of the United States of Cyprus. But, the Turks must never be deprived of their right to govern themselves." ${ }^{{ }^{61}}$ In return Turkey will expect to be admitted to the EU. The Cypriot Turks recent admission that they are willing to drop their demand to be recognized as an independent entity, if, in return, the international community 
acknowledges that the Republic neither speaks for nor represents them, did not signal a deviation from this basic Turkish stance.

According to Ersin Kalaycioglu, any settlement in Cyprus must meet several basic conditions. First, Greece and Turkey must abandon their claims to Enosis and Taksim (partition) respectively. Second, the Turkish minority must be granted equal political and sovereign rights. Third, there must be some kind of mechanism, which guarantees the Turkish minority's safety. Fourth, the TRNC's share of the island must shrink from the current 37 per cent to a size commensurate with its population. Fifth, several areas must be reserved for the re-settlement of refugees, while bearing in mind the situation in Cyprus since 1974. Sixth, all foreign troops must withdraw from Cyprus. Seventh, the island must be demilitarized, with only a police force left to keep order. Once these provisions are satisfied, negotiations for a final settlement can begin. In the course of the negotiations for, preferably, a united, federal republic, Turkey, Kalaycioglu argues, should - in light of the Greek Orthodox Church's past history and in order to curtail any Enosis-inspired zeal - insist upon a secular constitution. Only then may the newly established Federal Cypriot Republic start to negotiate its accession to the EU..$^{62}$

\section{The European Union}

Athens has managed, despite Turkey's custom union with the EU, to block the passage of EU aid money to Ankara. Only in 1999, in the wake of the talks between the two countries - more of which later - and Turkey's devastating earthquakes, did Athens deign to release the funds, which by then had reached the not inconsiderable sum of 500 million dollars. But, this was as far as cooperation between the two the sides went. Ankara, though grateful, still threatened to veto the admission of new NATO members should the Republic of Cyprus join the EU, while Athens warned that in the event of talks between the EU and TRNC it would blackball any future EU members. Athens justified its recalcitrant stance but arguing that it was acting for the benefit of its fellow EU states. After all, it explained, "we are simply telling the Turks, what you feel about them." ${ }^{63}$ Whatever the truth of the matter, Athens regarded its ability to block Turkey's accession to the EU as a major strategic asset.

While some European states perhaps secretly welcomed Greece obduracy, others deplored it. Greece insistence upon blocking Turkish membership, they remonstrated, dangerously polarized attitudes in Turkey. In January 1997, Klaus Kinkel, the German Foreign Minister publicly blamed Greece - its refusal to transfer EU money to Turkey - "for Turkey's Islamisation" which, he claimed, "largely due to Turkey's estrangement ... is the fault of the Greek element in the EU." ${ }^{64}$ The point behind Kinkel's and other similar strictures was that Turkish radicalism will be cut short the moment Europe - for which read Greece - stops alienating Turkey. These criticisms were hardly music to Greece's ear, and served to increase its own sense of alienation. 
The events in the Balkan did not help. There, for reasons of Orthodox solidarity, Greece, in stark opposition to the rest of NATO, declined to take action against the Serbs and side with the Bosnian Muslims. It justified its refusal to "act like civilised Scandinavians in the Balkans," by pointing out that it knows better than any one else the "pleasure" of living next to Muslims. Nevertheless the whole episode left it feeling isolated, its self-image "a lone wolf" more deeply entrenched than ever. ${ }^{65}$

Then at the end of 1990s, for reasons soon to be discussed, Greece reached the conclusion that if it wanted to modify Turkish policies it should start speaking with Ankara and that, therefore, a few concessions were in order. Its decision to sanction the Helsinki resolution, and allow Turkey to become a candidate for EU membership, marked a revolution in Greek policies. Greece's agreement to Turkey's candidature was not, however, condition free. Athens insisted that a solution to the Cyprus problem should no longer be considered a prerequisite to the Republic of Cyprus's accession to the EU. It was adamant that, henceforth, all Greek-Turkish territorial disputes be referred to the International Court of Justice at The Hague. Finally, it demanded that Turkey meet the same accession conditions as the other eleven EU candidates. In this context, Greece pointed to the need for a serious discussion of the human rights situation in Turkey, noting that, in order to qualify for EU membership, it, Turkey, will have to modify over 20,000 Turkish laws and regulations in line with the EU's human rights statutes. ${ }^{66}$

\section{Minorities and ethnic problems}

The minorities in the Greek provinces of Xanthi and Rodopi and in Western Thrace are another source of friction. Athens, i.e. the official Greek publication The Muslim Minority of Thrace: Minority Rights in a European State, considers them Muslim. ${ }^{67}$ Ankara insists that they are Turks and claims that they are subject to unfair restrictions, even persecution by the Greek authorities. A pamphlet published in 1998 by the Federation of Western Thrace Turks in Europe entitled: The Turkish Minority of Western Thrace accuses Greece of cultural and ethnic cleansing, just short of genocide. The pamphlet has both infuriated and alarmed Greece, which, seeing that the Federation's sole point of contact is a telephone number in Ankara and that it was distributed by the Turkish Foreign Ministry and various Turkish embassies, suspects that it is Turkey's handiwork. A second publication, The Macedonian Minority in Greece: A Human Tragedy within the Boundaries of the European Union, proved even more worrying. This pamphlet, issued by the Turkish Foreign Ministry not only accused Greece of atrocities against Greek Macedonians, but included maps identifying several regions within Greece as Macedonian.$^{68}$ Greece is nervous that, as in Cyprus, these allegations of ill treatment will be followed by active Turkish intervention on behalf of the Muslim minority and the creation of a new northern Cyprus in Greece itself. 
In like manner, Athens also links Turkey's close ties with the Muslim minorities along the Greek borders in FRYOM, Albania and Bulgaria, with events in Cyprus, pointing out that in all these cases Turkey insists that it is simply protecting the region's Turkish Muslim minority. With the Cypriot precedent constantly looming in the background, Athens frets that Turkey is not only bent upon helping the Muslim minorities challenge Greece's territorial integrity but might even intervene on their behalf. It is one reason why Athens views the Turkish land and naval units stationed permanently in Tirana and Albanian ports with suspicion and concern.

Greece has tried to meet the ethnic challenge with, among other things, demographic weapons. The Greece Orthodox Church announced "A Greek Plan to Spur Births", designed to increase the birth rate among Greek Orthodox families along the Turkish border. According to the plan, applied initially in northwestern Thrace, each Greek Orthodox family will receive a substantial subsidy for every third child born. ${ }^{69}$ At the same time, Greece has its own ethnicbased complaints against Turkey. The Greeks of Turkey: Under Threat of Elimination shrieks the title of one Greek publication. Athens also accuses Turkey of deliberately repressing Istanbul's Greek Orthodox community, a community, it notes, which in 1923 numbered 100,000 and in 1988 a mere 5,000. Athens has likewise made much of Turkey's now defunct Refah Partisi's - the Muslim Welfare Party - call to convert the Aghia Sophia into a mosque. And, while delighted with the US Congress's decision to appoint a commission of inquiry to examine the human rights situation in Turkey, Athens was outraged that the same commission was also charged with investigating the status of Thrace's minorities. ${ }^{70}$

Several other ethnic battles have infringed upon and played a part in the Greek-Turkish conflict. Greece, for instance, declared 24 April a Memorial Day, marking the deaths of the Armenians massacred, or so Greece claims, by the Turks during the First World War. Turkey's war with the PKK is another, more serious, example. Indeed, Athens viewed its links with the PKK as one of its few effective weapons against Turkey, assuming that the more resources Ankara wasted on the PKK, the less it could afford to open a second front against Greece. The last thing Athens wanted was a PKK-free Turkey at liberty to turn its attention to Greece. Similarly a Turkey flanked by a strong Iraq, Iran and Syria meant a harassed Turkey, which poses less of a threat to Greece. Hence Athens's strong protests to Israel following the Israeli-Turkish rapprochement. Greece accepted the Israeli argument that Turkey could have easily found an alternative to the supply of Israeli weapons. But Israel's cooperation with Turkey, Athens complained, by effectively neutralizing Syria, meant that Ankara was free to take action against Greece.

In view of all this, it is hardly surprising that when on 20 October 1998 Syria and Turkey signed an anti-terror agreement, alarm bells reverberated throughout Athens. The Adana Memorandum was preceded by a series of tough Turkish demands, accompanied by ominous declarations, such as Ismet Sezgin's, Turkey's Defence Minister, murmurings that "Turkey's patience is running out." 
There were also implicit threats of intervention, as when Turkey deployed hundreds of armored vehicles and several thousand troops along its 375 mile long border with Syria. In addition, the head of Turkish Intelligence was rumored to have warned his Syrian counterpart that "Turkey's military would enter Syria from one side, leave it from the other" - another version spoke of Turkish tanks rolling into Damascus within ten hours of crossing the border - unless the latter expelled Ocalan. All in all it proved a pretty successful mode of negotiation. Syria, for example, agreed to end its anti-Turkish campaign sparked off by Ankara's close contacts with Jerusalem, thus underlining the potency of the Turkish military threats. The Syrian-Turkish accord itself - partially brokered by Iran and Egypt - banned all PKK activity, including trade and commerce, in Syria. ${ }^{71}$ Syria further agreed to stop supporting the PKK and expel Ocalan. Finally, it undertook to persuade Lebanon to do the same. ${ }^{72}$ Thrown out of Syria, Ocalan was soon caught in Nairobi.

Proof of Turkey's military power and its ability to impose its will, without having to fire a single shot, the Syrian-Turkish accord reawoke all Athens's old fears of its neighbor to the east, plus some new ones. Turkey was clearly on a roll. It began with its humiliating indifference to the Greek deterrence, followed by its threat to bomb the S-300, which, in turn, forced Cyprus and Greece to back down and station the missiles in Crete. Now came Turkey's diktat to Syria to end its association with the PKK. The Adana Memorandum not only demonstrated, conclusively, Turkey's regional military dominance, but it gave it a decisive edge in its battle against the PKK at home and in northern Iraq. Moreover Turkey was now sufficiently confident to tackle the PKK's other patrons. Having pushed Ocalan out of Syria, it made sure that none of the European countries would grant him asylum. Turkey eventually caught up with Ocalan in Kenya, where he found refuge in the Greece embassy. His capture, again without Turkey firing a single shot, marked the beginning of the end of the war against the PKK.

Thus, two key players - Syria and the PKK - who had enjoyed intermittent Greek support and who by consuming a considerable portion of Turkey's time and resources, had diverting its attention away from Greece, had practically disappeared. Was it, Greece wondered, now its turn? Would it too be subjected to a Turkish diktat similar to the one addressed to Syria? The climate in Ankara did not appear promising. Ocalan's arrest, the Turkish media predicted menacingly, "is only the beginning ... Turkey has proved itself a feared enemy . . its adversaries have learned the hard way that no one can undermine the vital interests of our country." ${ }^{\prime 3}$ The fact that Turkey's Prime Minister at the time was Bulent Ecevit, the man not only responsible for Turkey's successes against the PKK, but who ordered Turkey's intervention in Cyprus in 1974, and certainly appeared in no mood for compromise, did not calm Greek nerves.

These developments, plus the assessment of Greece's and Turkey's relative military strengths, fuelled Athens' fears for the future, making the possibility of talks with Turkey suddenly an extremely attractive proposition. It was certainly, Athens thought, preferable to an armed conflict with a powerful 
and overconfident Turkey. Interestingly enough, Turkey too, for all its belligerent posturing, had no interest in an open military conflict with Greece, which would have a devastating effect on its relations with Europe. Moreover, Turkey was well aware that it would be negotiating from a position of strength. All this goes a long way toward explaining the current rapprochement between Greece and Turkey

\section{A breakthrough?}

In July 1999, after almost ten years of virtually no direct contact, Greece and Turkey embarked on a new round of talks. Given that the 1988 Davos accord resulted in nothing but disputes over interpretation, allegations of cheating, and shattered hopes, neither side was overly confident about the outcome of the current discussions ${ }^{74}$ Indeed, seeking to lower expectations, they admitted they would be extremely surprised if the talks produced any substantive or dramatic results. "We are not," George Papandreou, Greece's new Foreign Minister explained modestly, "aiming very high, merely to the point where we think we might achieve some results." His Turkish counterpart, Ismail Cem agreed, speaking of the effort to draw closer, "without raising expectations or being too assertive." ${ }^{\prime 5}$ Both believed that small steps forward in non-contentious areas such as environmental and cultural affairs, crime fighting, economic cooperation, even the removal of Greece's ban on EU aid payments to Turkey, were all that was possible at the time. However, once achieved, these will act as a springboard for further more complex negotiations over such intractable problems as Cyprus, the Aegean border, and Turkey's EU membership, which clearly demand a more favorable climate. ${ }^{76}$

Previous attempts at a Greek-Turkish rapprochement have proceeded at particularly leisurely pace. It took Greece and Turkey ten years to finally agree to implement the Confidence Building Measures (CBMs) - including a commitment to respect each others' sovereignty - drawn up in May and September 1989, following Andreas Papandreou and Ozal's meeting in Davos. The CBMs established guidelines reducing to a minimum the interruptions to civilian shipping and air traffic caused by military exercises on the high seas and in international air space. They also specified a code designed to prevent incidents and accidents on the high seas and in international air space, involving the two countries' air and naval forces. The Greek periodical COSMOS, for one, did not think that the ten-year time lapse between Davos and the CBMs' implementation augured well for the future. ${ }^{77}$

Yet these caveats, doubts, and reservations apart, the remarkable chemistry between Papandreou and Cem, who regularly refer to each other as "Dear George" and "Dear Ismail" did raise expectations similar to those evoked by the Davos accords. ${ }^{78}$ Some even harked back to the 1930s and the surprising friendship that sprung up between those two seemingly die hard enemies Eleftherois 
Venizelos and Mustafa Kemal, which led to the conclusion of several extremely satisfactory agreements between Greece and Turkey. ${ }^{79}$

\section{The reasons behind the thaw}

Several factors combine to explain the, on the face of it, surprising turn for the better in Greek-Turkish relations. The two violent earthquakes, which hit Turkey and Greece in August and September of 1999, resulted in a fierce outpouring of shared grief and sympathy. ${ }^{80}$ The mutual devastation and empathy were such that both, almost reflexively, sent humanitarian aid to help ease their neighbor's plight. The Ocalan affair, which could have led to an alarming deterioration in Greek-Turkish relations, was another factor serving as springboard for a renewed dialogue instead. It is worth mentioning in this context the Kurdish anti-Greek demonstrations throughout Europe, the seizure by Kurds of Greek legations in Europe and Kurdish accusations of Greek connivance in Ocalan's capture - despite the fact that it was Greece who gave him refuge in the first place - which led to bitter Greek recriminations concerning Kurdish perfidy and ingratitude. This made it easier for Greece to disassociate itself from the Kurdish cause, thus removing another source of conflict with Turkey. Events in the neighboring Balkans and above all the Kosovo crisis, provided a salutary shock to both countries as they found themselves not only on either side of the Balkan divide ethnically, religiously, politically, and even military, but also in danger of being sucked into the conflict. Not wishing to follow in the destructive path of the feuding Balkans states, Greece and Turkey decided that dialogue, even cooperation, is infinitely preferable to inflammatory unilateral steps or just plain estrangement.

Non-governmental groups and societies have also played their part in promoting Greek-Turkish relations, as has tourism, though not to begin with. In 1984, following the record number of Greeks who visited Turkey- several hundred thousand in 1982-83 - Ankara decided to exempt Greek tourists of the need to acquire visas. Unfortunately, as the most popular tourist sites proved to be the areas from which the Greeks were expelled during the 1920s, Greek tourism, at this point, did nothing but fan the flames of ethnic hatred. The number of tourists from both countries dropped dramatically, so that by 1985 only 130,000 Greeks visited Turkey and 200,000 Turks visited Greece. Things have improved since the thaw in Greek-Turkish relations, and especially since the 1999 earthquakes, with Turkey welcoming over 170,000 Greek tourists and 500,000 Turks spending their holidays in Greece. ${ }^{81}$

But, as John Sitilides correctly observed, much of the credit for the new positive climate should go to the private business sector. Early 2000 saw an unprecedented number of private initiatives in a number of diverse economic fields. These initiatives, engineered by entrepreneurs of various nations, range over a several countries and continents. Thus, Italian, Greek, and Turkish companies joined forces to build, within three years, a half-billion dollar energy plant 
which, using gas from Russia and run by the Exxon-Mobile Corporation, will provide Turkey with much needed power. Other examples include a Greek firm who purchased a Turkish mine, in order to export its raw materials to Europe and Africa for industrial, agricultural, and construction purposes. A natural gas network system is also planned, which, linking Greece to Turkey, and allowing the latter to purchase surplus Greek gas, will meet Turkey's huge energy demands. There is also a joint Greek-Turkish venture, funded by the EU, to construct high-voltage transmission lines which will deliver electricity to the Balkans. A Greek plant, which uses Turkish technology to manufacture plastic irrigation pipes for the Balkan market, is another joint Greek-Turkish initiative. Finally, there are plans to install environmentally sensitive wind-power production systems in Greece and Turkey, thus relieving, to a degree, their grave urban pollution problems. ${ }^{82}$

That same year, Turkey held an exhibition in Athens promoting Turkish exports, including textiles, chemical products, medical instruments, and consumer goods. It proved a huge success as dozens of Greek companies rushed to buy Turkish goods, especially textiles and ready-made clothes. Not surprisingly there are now plans for an Athens-based Greek-Turkish Chamber of Commerce. At the end of February 2000, 140 Greek businesspeople met in Istanbul with their Turkish counterparts to discuss ways of overcoming obstacles to trade such as tariffs and dual taxation, and of boosting export subsidies. They also explored the possibilities of new joint business ventures mostly in the Black Sea region. ${ }^{83}$

Trade clearly played an important part in promoting the Greek-Turkish rapprochement. In 1995, trade between the two countries - with a combined population of over 75 million people - was a mere 411 million dollars. By 1998, it was 690 million. ${ }^{84}$ Then came 2000 a year with a profusion of private economic initiatives. It is evident that as trade and economic cooperation increase, as more people, companies and countries are involved in joint ventures, and as the profits from these initiatives mount and, with them, the reluctance to lose all that has been invested and gained, so will the number of parties who have a vested interest in good relations grow. As a result, politicians and soldiers will find it increasingly difficult to check, let alone reverse, the current thaw in Greek-Turkish relations. Indeed, as far back as 1996 a meeting of Greek and Turkish business entrepreneurs concluded that once the annual trade between the two countries reached the 2 billion dollar mark, soldiers and politicians would be much less eager to orchestrate crises. ${ }^{85}$

As for the politicians, in Greece, Pangalos's dismissal and replacement by more a moderate politician clearly helped the cause of reconciliation. So did the obvious chemistry between George Papandreou and Ismail Cem, Greece and Turkey's current Foreign Ministers, who, incidentally, are both trained sociologists. At the same time, and paradoxically, the fact that Turkey's Prime Minister is Bulent Ecevit, the man who ordered Turkey's invasion of Cyprus and orchestrated Ocalan's capture, augurs well for any future negotiations. Given his past history, Ecevit can afford to make concessions without fear of being accused of 
being weak or unpatriotic. His image as a strong man will certainly come in useful in dealing with Turkey's nationalists and the TRNC's inevitable complaints once a painful compromise over Cyprus is hammered out. The Greek Prime Minister, Costas Simitis, has already had to overcome charges of lack of patriotism, when he rejected the "so called super patriots" demand to "Kurdify Greek foreign policy." ${ }^{86}$ The chances of Ecevit being subjected to a similar browbeating are very small indeed.

\section{First steps}

The path ahead of Greece and Turkey is both long and thorny. There is little hope, for example, of a compromise over the Aegean. Athens insists that its territorial rights in the Aegean are not open to negotiation and that any dispute should be turned over to the International Court of Justice. Turkey, however, does not recognize the court's jurisdiction and is adamant that the two resolve their Aegean disagreements between them. The prospects for a meeting of minds over Cyprus are not much better. This despite Ankara's acute sensitivity to the fact if it fails to meet mounting international expectations it will be the one branded bull-headed and intractable. ${ }^{87}$

Nevertheless these knotty issues apart, between 1999 and 2000, GreekTurkish relations underwent a radical transformation. September 1999 saw talks between Greece and Turkey on a whole range of issues, including cultural and economic affairs, energy production, anti-seismic safety measures, and security matters. The mayors of Athens and Istanbul visited each other and signed a protocol on cultural, trade, tourism, and technical cooperation. In addition, both sides announced measures that augured well for the future. Sabahattin Cakmakoglou, the Turkish Defence Minister, promised, in light of the recent improvement in Greek-Turkish relations, to reduce the number of Turkish military exercises in the Aegean, while admitting that some of them may have been "carried out for political reasons connected to our neighbours." He added that, "Repeated exercises constitute an additional cost for the economy." ${ }^{8}$ The Turkish air force agreed not only to accept the Athenian FIR, but to remove all ammunition from planes flying over the Aegean. Meanwhile, in Greece, Dimirtis Apostolakis, Greece's Deputy National Defense Minister's conceded that Athens did not consider Israeli-Turkish military cooperation a threat, an admission as surprising as it was refreshing. His hope that no one in Greece will even think of the two countries' association as an anti-Greek axis is far removed from Pangalos's offensive depiction of Israel and Turkey as "evil states." 89

That same month a Turkish football team, the Marmara Sports Club, played a charity match in Rhodes, to raise money for the Turkish and Greek earthquake victims. Among the fans accompanying the club was the former Turkish President, General Kenan Evren. The Greek press, harking back to previous GreekTurkish sporting events, which resembled battlefields rather than sports 
meetings, noted how "not too long ago the arrival on a Greek island of a senior Turkish General, retired or not, dozens of Turkish reporters and a group of young Turks would have inflamed many sections of [Greek] society." This was clearly no longer the case. The Turkish journalist, Yorgo Kirbaki, was also struck by the changed atmosphere. In the past, he wrote, matches between Greece and Turkey in the PAOK Thessaloniki stadium were "hell on earth, it being almost impossible to leave the stadium in one piece." But, he enthused, the September 1999 match between PAOK and Galatasaray, "was heaven ... I remember neither the match nor the goals. But who cares? Turks and Greeks under the same sky hugged one another and prayed for a peaceful tomorrow, filled with friendship and love!"90

In November 1999, there began a new round of UN-brokered proximity talks over Cyprus, while President Clinton visited both Greece and Turkey. December saw a major breakthrough in the countries' relations, with Greece finally lifting its veto on Turkey's candidacy for the EU. Meanwhile, Turkey, having first removed the Heybeliada Clerical School in Istanbul, closed since 1971, from the control of the Fener Greek Orthodox Patriarchate and placed it under the its own authority, and then setting up a body - The High Religious Council Administration, part of Istanbul's University's School of Theology - to monitor the Orthodox education provided by the school, promised to reopen the school, thus removing one more bone of Greek-Turkish contention. ${ }^{91}$ Finally, the Greek football federation decided, in December 1999, to put in, together with its Turkish counterpart, a bid to host Euro 2008.

Throughout these months a record number of Greek companies have contacted the Turkish embassy in Athens in search of Turkish partners with which to do business in Turkey. Athens hinted that it might recognize the existence of a Turkish minority in Western Thrace, going so far as to admit that they are not "Muslimized Greeks" and that "there is no need to repeat the sins of past." In return, Greece expected comparable improvements in the position of Istanbul's Greek citizens. ${ }^{92}$ Representatives of Greek and Turkish municipalities in the Aegean met to discuss common problems. A modern Turkish history exhibition was sent to Thessaloniki and Athens aboard Mustapha Kemal's personal railway car. A Turkish Friendship Train carrying rail workers, journalists and emergency personnel, and whose purpose was to bolster the new and positive discourse between the two countries' media, arrived in Thessaloniki just as the Turkish Consulate there was marking the sixty-first anniversary of Kemal Atta Turk's death. ${ }^{93}$

In January 2000, the Greek Foreign Secretary paid an official visit, the first since 1962, to Ankara. Greece and Turkey also concluded a series of bilateral agreements on illegal immigration, combating terrorism, cross-border crime, fraud and organized crime, money laundering, duplicate taxation, shipping, science and technological co-operation, and environmental protection. Not surprisingly, John Sitilides thought this to be "the most intense period of diplomatic engagement between Greece, Cyprus, Turkey and the United States, in years." ${ }^{94}$ 
There has also been remarkable progress on the military front. In the early summer of 1999, Turkish military planes carrying humanitarian aid to Kosovo were allowed to fly over Greece. A short time later, a 1,400-strong Greek force took part in peacemaking operations in Kosovo alongside Turkish troops. Overall, since 1994 about 2,020 Greek and 2,360 Turkish troops have served together in UN and NATO missions, first in Bosnia and then in 1999 in Kosovo. ${ }^{95}$ October 1999 saw the official opening of NATO's Joint Southern Command Center, in Larissa, Greece, born of the Alliance's recent reorganization. It is one of four subregional NATO headquarters, the remaining three are situated in Izmir in Turkey, Verona in Italy, and Madrid in Spain. Greeks and Turks work closely together in both Larissa and Izmir. A Turkish Major General is the Larissa's Center's Chief of Staff, while a Greek Major General holds the same position in Izmir. The newly formed South East European Brigade (SEEBRIG) is a joint Greek, Italian, and Turkish venture. This seven-nation regional task force is currently commanded by a Turkish Brigadier General, while a top Greek Defense Ministry official oversees its policies. The brigade's headquarters, at present in Bulgaria, will move to each of its member states in turn. ${ }^{96}$

In early June 2000, 150 Turkish marines, provided with air cover by ten Turkish jet fighters, landed on Greek shores as part of a NATO training exercise. Athens also agreed to let Turkish warplanes to fly over Greece while en route elsewhere. And, it announced its intention to vacate the Andros and Psathoura shooting ranges located in the middle of Aegean's international air space. In the meantime, back in Turkey, a bold plan was drawn up for the dissolution of the 100,000-strong Turkish Aegean Army, established in 1975 in response to the rising tension with Greece and stationed only a stone's throw away from the Greek forces in the Greek Aegean islands. In return, Turkey expected Greece to make several concessions over the Aegean. The plan, which many in Turkey thought premature, was eventually shelved. Nevertheless, the mere fact that senior Turkish officials, such as Admiral Guven Erkaya, Prime Minister Ecevit's personal advisor, cast doubt on the future of the hitherto sacrosanct Aegean Army is clear evidence of the fresh winds blowing in Turkey. ${ }^{97}$

\section{The future}

It remains to be seen whether the thaw in Greek-Turkish relations will have longterm and lasting results. There remain, despite the friendly even accommodating atmosphere, several serious differences between the two countries, particularly over questions of sovereignty and flying rights in the Aegean. There Greece and Turkey still intercept each other's aircraft, on the dubious grounds that they have violated the Turkish or Greek Aegean islands' air space, as happened during a NATO exercise in October 2000 over the islands of Lemnos and Ikariya.

On the whole, however, Greece and Turkey seem anxious to confine their disputes to the rhetorical level, though when compared to the aggressive and 
nasty war of words which had hitherto characterized the two countries' relations, their recent declarations have been remarkably temperate, even tame. Even more striking are the pacific and conciliatory statements issuing from both sides of the Aegean. Bulent Ecevit has admitted that Turkey has no territorial designs on Greece, adding that there are no real conflicts of interest between Ankara and Athens. This sentiment was echoed by the Greek Prime Minister, Simitis, who claimed that the delineation of the Aegean continental shelf is Athens's sole remaining dispute with Turkey, the implication being that all the other stumbling blocks to better relations, including apparently Cyprus, have been removed. These seem to be slightly extravagant claims, and the Greek government's spokesman was probably closer to the mark when he described the current state of relations between Greece and Turkey as one of "non tension." 98

The fate of Turkey's bid for EU membership, will have a decisive effect on future Greek-Turkish relations. George Papandreou, underlined this point when he urged not to let "the momentum that has developed [following Turkey's candidacy] go to waste.” It was, he emphasized, "of vital importance... that Turkey's candidacy did not remain on paper ... Greece had endorsed an authentic candidacy, which anticipated the actual rather than sham prospect of Turkey joining the EU." Once Turkey realizes that its accession to the EU is assured, it might well become more flexible as regards other outstanding Greek-Turkish quarrels. Better still, welcomed by Europe, Turkey's acute sense of isolation, alienation, even siege will wither away, and this, in turn, may help resolve the questions, such as the Kurdish issue, dividing Turkey and the EU. ${ }^{99}$

Conversely, once Turkey joins the EU Athens will begin to regard its neighbor to the east as a European rather than exclusively Greek problem. Incidentally, the Kurdish demonstrations throughout Europe, following Ocalan's arrest, made it clear that Turkey is indeed a European issue. As a result, Greece will expect various European bodies to deal with Turkey. No longer compelled to act as Europe's anti-Turkish spokesman or spearhead the EU's anti-Turkish policies, Greece will be relieved of its self-imposed burden of confronting Turkey for Europe's sake. This, in turn, will lead to marked improvement in Greece's relations with Turkey and, no less importantly, Europe. No longer in Europe's "bad book," Greece's conviction that it is "a lone wolf," might disappear to be replaced by the gratifying sense it is looked upon kindly by its fellow EU members.

How else will a lasting thaw or, better still, a future settlement benefit Turkey and Greece? For one thing, it will mark the end of 500 years of HellenicTurkish enmity, at least on paper. It will allow Greece to settle its territorial disputes with Turkey. A prospective territorial settlement will, in all likelihood, designate those areas that may be reasonably considered Hellenic sovereign Greek territory. In return, however, Greece will have to give up its Megali Idea ambitions and Greek irredentism will come to an end. It will be worth it as, for the first time in history, instead of being threatened by Turkey, Greece's borders will enjoy Turkey's blessing. Moreover, no longer the sole member of the EU embroiled in an international ethnic, political, and military conflict, Greece's 
process of integration into Europe will move swiftly ahead. It would, for example, be given the aid it needs to meet EMU economic and financial standards. As a result instead of being, as it currently is, the least economically inspiring member of the EU, Greece's financial and economic situation may take a turn for the better.

Turkey will benefit equally. The sweeping Greek-Turkish ethnic and international conflict will no longer bar - at least on paper - Turkey's way westwards toward acceptance as a European country. Greece may even be willing to give Turkey a hand in attaining this far from easy goal. Thus, at long last, the centurylong Kemalist quest to became a part of Europe will be attained, with all the credit going to the Turkish Kemalist government. This will no doubt strengthen the government's hand, as will the fact that internally Islamic and radical nationalism, which fed on Greek and European animosity, will fade away. A friendly Greece may also help clear the way towards an improvement in Turkey's relations with the Orthodox world, including, and above all, Russia. The two might even cooperate to stabilize the ever turbulent Balkans. Above all, once its conflict with Greece is over, Turkey will be able to celebrate the truly remarkable achievement of not having been directly involved in a major war for almost a century. It is a record not many countries, especially in the Middle East and east Mediterranean, can match. True there was Korea and Cyprus. But the former was Turkey's meal ticket into NATO and took place thousands of miles from home, while the latter was a military picnic. In sum, never will Ataturk's promise of "peace at home and peace abroad," be closer to fulfillment.

\section{Notes}

1 Bulent Ecevit, a poem, reprinted by the Turkish Daily News, 19 February 1999.

2 The Economist, 14 January 1989.

3 Vamik D. Volkan and Norman Itzkowitz, Turks and Greeks: Neighbours in Conflict, Huntingdon, Eothen Press, 1994, p. 167.

4 Dankwart A. Rustow, Turkey: America's Forgotten Ally, New York, Council on Foreign Relations, 1987, p. 15.

5 Daily News Bulletin (DNB) (Athens News Agency), 12 December 1996.

6 Argyrios K. Pisiotis, "French and German, Greek and Turk: 'Hereditary Enmity,' U.S. Hegemony, and the Limits of Integration," Athens, Research Institute for European Studies, Research Paper No. 9, January 1995, p. 32.

7 Berdal Aral, “Turkey's Insecure Identity from the Perspective of Nationalism," Mediterranean Quarterly, Vol. 8, No. 1, Winter 1997, p. 84; Van Coufoudakis, presentation, American Hellenic Chamber of Commerce and the Brookings Institute, Panteion University of Social and Political Sciences, conference on "USA-Greece-Turkey in the Emerging International System," Athens, 17-19 June 1993; Ayten Gundogdu, "Identities in Question: Greek-Turkish Relations in a Period of Transformation?," MERIA Journal, Vol. 5, No. 1, March 2001, p. 4.

8 Athanassios G. Platias, “Greece's Strategic Doctrine: In Search of Autonomy and Deterrence," in Dimitri Constans (ed.), The Greek-Turkish Conflict in the 1990s, London, Macmillan, 1991, pp. 94, 96. 
9 The Economist, 27 July 1991.

10 George Papandreou, Greece's Foreign Minister since 1999, was at the time Minister of Education. George Papandreou, "Greece, the United States and their Mutual Common Interests in the Balkans," in Theodore A. Couloumbis, Thanos M. Veremis, and Thanos Dokos (eds), The Southeast European Year Book 1993, Athens, Hellenic Foundation for European and Foreign Policy (ELIAMEP), 1994, p. 19; Ekavi Athanassopoulou, "Ankara's Foreign Policy Objectives After the End of the Cold War," Orient, Vol. 36, No. 2, 1995, p. 273.

11 DNB, 28 September 1996. For details on the Imia/Kardak incident see Andre Gerolymatos, "The Military Balance of Power Between Greece and Turkey: Tactical and Strategic Objectives," in Aldo Chircop, Andre Gerolymatos, and John O. Iatrides, (eds), The Aegean Sea after the Cold War: Security and Law of the Sea Issues, London, Macmillan, 2000, pp. 48-49; Athanassios G. Platias, "Greek Deterrence Strategy," in Aldo Circop, Andre Geolymatos, and John O. Iatrides (eds), The Aegean Sea after the Cold War: Security and Law of the Sea Issues, London, Macmillan, 2000, p. 66.

12 Platias, "Greece's Strategic Doctrine," pp. 97-98.

13 Ibid.; Platias, "Greek Deterrence Strategy," pp. 69-70. Turkey's and Greece's GDP for 1997 were 207.5 billion dollars and 124 billion dollars, respectively. Their GDP growth rates were 4.1 percent and 3.2 percent respectively. See The Economist, reprinted in Ha'aretz, 21 December 1998.

14 Platias, “Greece's Strategic Doctrine," pp. 100-101, 103; Platias, “Greek Deterrence Strategy," p. 73.

15 DNB, 27 September 1997.

16 Volkan and Itzkowitz, Turks and Greeks, pp. 169, 179, 181-182.

17 DNB, 8 March 1996.

18 Turkish Daily News (TDN), 19 February 1999. Also dismissed, following their part in the Ocalan affair, were the Greek Interior Minister, Alekos Papadoploulos, and the Minister for Public Order, Philipos Petsalnikos. On Pangalos's outburst in July 1998, during which he pilloried President Clinton, calling him “a liar," see also Kathimerini (Greek), 31 December 1998. TDN, 2 February 1999, reported that on 6 January 1999 the Turkish Justice Ministry announced that women and young girls would no longer have to undergo virginity tests.

19 DNB, 15 May 1996.

20 DNB, 19 August and 18 December 1996, DNB, 27 September 1997.

21 Birsan Iskenderoglu, "Turkey vs. the West", TDN, 20 February 1999; Interview with Ambassador Nezeretis, TDN, February 16, 1999 (emphases in the original).

22 Milliyet, 17 December 1997; Turkistan Newsletter, Vol. 98-2:081, 28 April 1998; TDN, 23 February 1999. For the Lavrion camp see Time, 30 March 1998; DNB, 22 March 1997.

$23 \mathrm{Ta} \mathrm{Nea}$ (Greek), 20 August 1999; Hurriyet (Turkish), 21 August 1999; Sabah (Turkish), 20 August 1999; Gundogdu, "Identities in Question," p. 8.

24 Victor S. Papacosma, "More than Rocks: The Aegean's Discordant Legacy," Mediterranean Quarterly, Vol. 7, No. 4, Autumn 1996, pp. 86-87.

25 TDN, 2 February 1999.

26 See also Van Coufoudakis, Presentation; Papacosma, "More than Rocks," p. 83; Platias, "Greece's Strategic Doctrine," p. 93.

27 Papacosma, "More than Rocks," pp. 87-88; Thanos Veremis, "The Ongoing Aegean Crisis," Thesis, Vol. 1, No. 11, Spring 1997, pp. 22-32; Gerolymatos, "The Military Balance of Power Between Greece and Turkey," pp. 53-54.

28 Gerolymatos, “The Military Balance of Power Between Greece and Turkey," p. 55.

29 Institute of International Relations, Panteion University, Athens, COSMOS, Vol. 2, No. 8, July-August 1998, p. 2.

30 Ibid. 
31 Gerolymatos, "Military Balance of Power Between Turkey and Greece," p. 55; DNB, 14 November 1996; Platias, “Greek Deterrence Strategy,” p. 180.

32 TDN, 7 April 1997; TDN, 10 May 1999.

33 TDN, 9 March 1999.

34 TDN, 19 and 23 February 1999; TDN, 2 March 1999; Turkish Probe, 21 February and 7 March 1999.

35 On the cost of Turkey-PKK war see Milliyet, 23 January 1998; Christian Science Monitor, 22 April 1998; TDN, 18 February and 30 June 1999; Tamar Gabelnick, William D. Hartung, and Jennifer Washburn, Arming Repression: U.S. Arms Sales to Turkey during the Clinton Administration, a joint report of the World Policy Institute and the Federation of American Scientists, October 1999, available at www.fas.org/asmp/library/reports/ turkeyrep.htm.

36 Hurriyet, 18 August 1999; TDN, 21 March 2000; TDN, 14 and 28 April 2000. In April 2000, the Turkish military and Foreign Ministry considered possible cuts in the Turkish arms procurement program. Officially the reason was the economic devastation caused by the August 1999 earthquake. In addition, Confidence Building Measures, including military cutbacks, implemented by Turkey's neighbors were regarded as an incentive for similar steps on Turkey's part. At the same time, however, the Turkish Defence Minister, Sabahattin Cakmakoglu, announced an increase in the country's weapons procurement, to the tune of 145 helicopter gunships, 1,000 main battle tanks, and 8, instead of 4, airborne early warning aircraft. Cakmakoglu warned that Turkey's much improved relations with Syria and Greece should not delude the Turks into thinking that the planned armament programme was no longer necessary. He then added, perhaps to silence potential critics, that while Turkey's military budget is 8.8 per cent of its national budget, that of other NATO members is 10-20 per cent.

37 Thassos Giannitsis, "Greece and the European Economic and Monetary Union," Thesis, Vol. 1, No. 1, Spring 1997, pp. 13-21; Ha'aretz, 16 January 2000. One of the conditions Greece had to meet before it joined the EMU was to stabilize the drachma's rate of exchange against the euro, with 15 percent being the most it may fluctuate. Greece's poor growth record in the 1980s and 1990s should be set against its impressive performance between 1960 and 1972 when, at 6.2 percent, its average annual growth rates were the highest in Europe and North America. See also COSMOS, Vol. 2, No. 6, March-April 1998, p. 1.

38 Lawrence Korb, presentation, The American Hellenic Chamber of Commerce and the Brookings Institute, Panteion University of Social and Political Sciences, conference on "USA-Greece-Turkey in the Emerging International System," Athens, 17-19 June 1993.

39 On the history of the 7:10 ratio see Ellen Laipson, "Greece and Turkey: The Seven-Ten Ratio in Military Aid," Congressional Research Service (CRS), The Library of Congress, CRS Report for Congress 90-29 F, revised 26 December 1989.

40 Gabelnick, Hartung, and Washburn, Arming Repression.

41 TDN, 17 March 1999.

42 On the Jewish lobbies' assistance see Yasemin Dorba-Manco, "Jewish-American Organisations Lobby for Silk Road Initiative," interview with Daniel Mariaschin, Director, B'nai B'rith International Centre for Public Policy, TDN, 28 July 1999; Barry Jacobs, "The Role of the American Jewish Community in Fostering Relations and as a Friend of Turkey," lecture, Istanbul, Marmara Hotel, 10 June 1999. For Ambassador Kandemir's see TDN, 26 March 1998.

43 According to the Cypriot Republic Department of Statistics and Research at the end of 1997, Cyprus's total population was 746,000, compared with 741,000 the previous year. Of these, 658,000 Cypriots lived in the government-controlled area, and 88,000 in the northern part of the island. The 114,000 Turkish settlers were not included in the department's estimate. The ethnic breakdown of Cyprus's population at the end of 1997 
was 84.1 percents Greek-Cypriot, 11.8 percent Turkish-Cypriot, 0.6 percent Maronite, 0.3 percent Armenian, 0.1 percent Latin, and 3.1 percent foreign residents, mostly British and Greek. The same year (1997) saw 9,275 births, compared with 9,638 the previous year, pointing to a decline in the island's fertility rates: 2.00 for 1997, compared with 2.08 the previous year. For demographic data on Cyprus see Kathimerini, 26 January 1999. Also Gregory R. Copley, “Turkey, so Close to the Promise of Ataturk, Sees its Promise Options Withering," Defence and Foreign Affairs Strategic Policy, Vol. 27, No. 7, July 1999.

44 Avrupa, quoted in DNB, 7 December 1999.

45 DNB, 28 December 1996.

46 DNB, 2 December 1996.

47 Copley, "Turkey, so Close to the Promise of Ataturk, Sees its Promise Options Withering."

48 A. Gerolymatos, lecture, BESA Center for Strategic Studies, Bar-Ilan University, Israel, February 1997; Gerolymatos, "Military Balance of Power," p. 57.

49 TDN, 19 February 1999.

50 Mike Georgiou and Mary Papatzian, "Greece and Turkey: Playing the Power Game - and Loosing," Athens Watch, 2 August 1998; Ha'aretz, 31 December 1998.

51 On the Greek deterrence theory vis-à-vis Turkey see Athanassios Platias, "Greek Deterrence Strategy," in Constantine Arvanitopolous (ed.), Security Dilemmas in Euroasia, Athens, Institute of International Relations, Panteion University of Social and Political Sciences, 1999, pp. 181-183.

52 Christopher Brewin, Proceedings of a Panel Discussion, "Why Cyprus Entry into the European Union Would be Illegal," the Turkish Embassy, London, 8 November 2001, p. 13.

53 Maurice H. Mendleson, Keynote Speech, the Turkish Embassy, London, 8 November 2001, p. 9.

54 For an excellent analysis of the Turkey's Cypriot policies see Ersin Kalaycioglu, "Troubled Waters: Cyprus and Turkish Foreign Policy," Istanbul, Bogazici University, undated, mimeograph; Alan Makovsky, "Turkey and the Bush Administration: The Question Marks,” Policywatch, No. 527, 30 March 2001.

55 The Economist, reprinted in Ha'aretz, 25 July 2000.

56 Kalaycioglu, “Troubled Waters,” p. 7.

57 Zvi Barel, Ha'aretz, 24 January 2000.

58 Kalaycioglu, "Troubled Waters," pp. 8, 10.

59 Aral, “Turkey's Insecure Identity from the Perspective of Nationalism," pp. 84-85.

60 Clement H. Dodd, "Turkey and the Cyprus Question," in Alan Makovsky and Sabri Sayari (eds), Turkey's New World: Changing Dynamics in Turkish Foreign Policy, Washington, DC, Washington Institute for Near East Studies, 2000, pp. 153-154, 168.

61 Star, 10 March 2000.

62 Kalaycioglu, “Troubled Waters," p. 13.

63 Author's interview with Foreign Ministry officials, Athens, August 1999.

64 DNB, 9 January 1997.

65 Loukas Tsoukalis, "Is Greece an Awkward Partner?," in Kevin Featherstone and Kostas Ifantis (eds), Greece in a Changing Europe: Between European Integration and Balkan Disintegration, Manchester and New York, Manchester University Press, 1996, p. 28. Athens was considered one of Serbia's staunchest allies. Before the outbreak of the war in Kosovo in March 1999, Greece was one of the biggest investors in Yugoslavia having, over a twoyear period, poured some 1 billion dollars into the country. It has also invested around 70 million dollars in Bulgaria, 85 million in Romania and another 70 million in FYROM. Kathimerini, 4-5 September 1999.

66 DNB, 11 December 1999; John Sitilides, Western Policy Centre, Washington, DC, 12 October 1999. 
67 Hellenic Republic, European Perspectives, Economic and Foreign Policy Issues, Athens, Ministry of Foreign Affairs and Ministry of Press and Mass Media, 1997.

68 Turkish Ministry of Foreign Affairs, The Macedonian Minority in Greece: A Human Tragedy within the Boundaries of the European Union, Ankara, Ministry of Foreign Affairs of Turkey, May 1999.

69 International Herald Tribune, 11 March 1999.

70 Hellenic Republic, European Perspectives, Economic and Foreign Policy Issues.

71 Arabies Trends, January 2001, p. 20. The PKK controlled much of the drug trade to and from Turkey, the Bqa'a valley, and the "Safe Haven" in northern Iraq. Between 1984 and 1999, while fighting the PKK, the Turkish army seized 13,363 kilos of hashish, 4,255 kilos of morphine, 2,502 kilos of heroin and 621 grams of cocaine. See TDN, 12 March 1999.

72 Ha'aretz, 7 December 1998, reported that since the October 1998 agreement, Syrian newspapers have toned down their criticism of Turkey, which reached new heights following the latter's growing contacts with Israel.

73 Ilnur Cevik, editorial, TDN, 17 February 1999.

74 Andreas Papandreou and Turgut Ozal, the Greek and Turkish Prime Ministers respectively, met in Davos, Switzerland, in January 1988. The meeting paved the way for a series of agreements between the two countries, including a memorandum on confidence-building measures, guidelines for the prevention of incidents on the high seas and in international air space, and a decision to establish two joint committees to discuss closer political and economic relations.

75 TDN, 4 July 1999.

76 TDN, 1 July 1999.

77 Panteion University, Athens, Institute of International Relations, COSMOS, Vol. 2, No. 6 March-April 1998.

78 See correspondence between the two, TDN, 1 July 1999.

79 In 1930, the Greek Prime Minister, Eleftherios Venizelos, "the most important political figure in modern Greece history" (Thanos M. Veremis and Mark Dragoumis, Historical Dictionary of Greece, London, Scarecrow Press, 1995, p. 177), signed a treaty of friendship with Turkey, a mere eight years after the Asia Minor debacle. The treaty was to usher in a decade of good relations between Greece and Turkey. See Richard Clogg, A Short History of Modern Greece, Cambridge, Cambridge University Press, 1979, pp. 126-127. See also Lord Kinross, Ataturk: The Rebirth of a Nation, London, Weidenfeld and Nicolson, 1964, p. 459.

80 On EMAK, the Greek rescue team, and on rescue operations in Turkey, see Kathimerini, 19 August 1999; Eleftrotipia, 20 August 1999.

81 DNB, 27 December 1999.

82 All the information on the Greco-Turkish private sector is taken from John Sitilidis, Regional Integration in Southeastern Europe, Washington, DC, Western Policy Centre, 2 March 2000.

83 Ibid.

84 Under- Secretariat of Foreign Trade of the Turkish Prime Ministry, TDN, 10 July 1999.

85 DNB, 9 December 1996.

86 TDN, 2 March 1999.

87 DNB, 11 December 1999; John Sitilides, Western Policy Center, Washington, DC, 12 October 1999.

88 DNB, 27 September 1999.

89 Ibid.

90 DNB, 25 September 1999; Radikal, 2 and 4 September 1999.

91 Hurriyet, 17 December 1999.

92 Radikal, 30 July and 2 August 1999.

93 Western Policy Center, The Strategic Regional Report, Vol. 4, No. 7, 1999. 
94 John Sitilides, "Much Ado in the Eastern Mediterranean," Western Policy Center, New York, 15 September 1999; Western Policy Center, The Strategic Regional Report, Vol. 4, No. 7, 1999.

95 On the UN invitation to Turkey to participate in the peacekeeping force in Bosnia, see Ekavi Athanassopoulou, "Ankara's Foreign Policy Objectives after the End of the Cold War," Orient, Vol. 36, No. 2, 1995, p. 283.

96 Harry Dinella, “Imia, NATO, and Alpha Centauri," Western Policy Center, Washington, DC, Regional Report, Vol. 6, No. 2, March 2001; John Sitilides, "Regional Integration in Southeastern Europe," Western Policy Center, Washington, DC, 2 March 2000.

97 Milliyet, 22 May 2000.

98 DNB, 20 September 1999; DNB, 14 December 1999.

99 Ibid. 